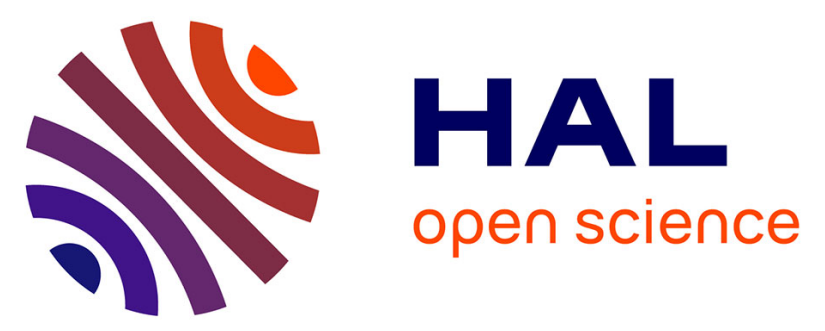

\title{
Characteristics of Acacia mangium shoot apical meristems in natural and in vitro conditions in relation to heteroblasty
}

Clémence Hatt, François Mankessi, Jean-Baptiste Durand, Frédéric Boudon, Fabienne Montes, Marc Lartaud, Jean-Luc Verdeil, Olivier Monteeuis

\section{To cite this version:}

Clémence Hatt, François Mankessi, Jean-Baptiste Durand, Frédéric Boudon, Fabienne Montes, et al.. Characteristics of Acacia mangium shoot apical meristems in natural and in vitro conditions in relation to heteroblasty. Trees - Structure and Function, 2012, 26 (3), pp.1031-1044. 10.1007/s00468012-0680-0 . hal-00699815

\section{HAL Id: hal-00699815 https://hal.inria.fr/hal-00699815}

Submitted on 12 Aug 2013

HAL is a multi-disciplinary open access archive for the deposit and dissemination of scientific research documents, whether they are published or not. The documents may come from teaching and research institutions in France or abroad, or from public or private research centers.
L'archive ouverte pluridisciplinaire HAL, est destinée au dépôt et à la diffusion de documents scientifiques de niveau recherche, publiés ou non, émanant des établissements d'enseignement et de recherche français ou étrangers, des laboratoires publics ou privés. 


\section{Characteristics of Acacia mangium shoot apical meristems}

\section{in natural and in vitro conditions in relation to heteroblasty}

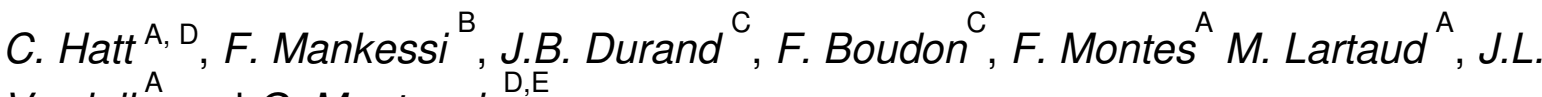
Verdeil $^{\mathrm{A}}$ and $O$. Monteuuis

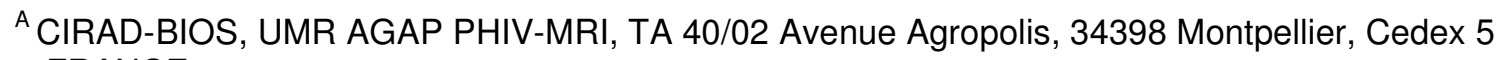
FRANCE.

B

CRDPI, B.P 1291 Pointe-Noire, CONGO.

${ }^{C}$ CIRAD-BIOS, UMR AGAP and INRIA, Virtual Plants, TA A-96/02, Avenue Agropolis, 34398 Montpellier, Cedex 5 FRANCE.

D CIRAD-BIOS, UMR AGAP, TA A-108/03- Avenue Agropolis, 34398 Montpellier Cedex 5 FRANCE.

E Corresponding author. E-mail: olivier.monteuuis@cirad.fr 
Abstract. The influence of heteroblasty on morphological and histocytological characteristics of Acacia mangium shoot apical meristems (SAMs) was assessed comparing materials with mature and juvenile leaf morphology in natural and in vitro conditions. SAM dome height $(H)$, basal diameter $(D)$ and shape $(S)$ varied significantly according to the four origins of plant material investigated. $\mathrm{H}$ and $\mathrm{D}$ were highly correlated, with bigger values for the mature source from outdoors "Mat" than for the other origins. Mat SAMs scored also the higher values for the size and the number of cells of the two tunica layers (L1 and L2), the central mother cells $(\mathrm{CMC})$, the peripheral zone $(\mathrm{PZ})$ and the combination of these four SAM zones (4CZ). Overall, cells were noticeably more vacuolized in SAMs from Mat and also from the mature ("IVM") and juvenile-like "IVJ" in vitro origins than in those from the outdoor juvenile source "Juv". These latter were characterized by larger cells and nuclei for L1 and L2 tunica layers, whereas Mat SAMs showed smaller nuclei and nucleoplasmic ratios for L1, L2, CMC and PZ zones. Some Mat SAM nuclei looked densely stained by NBB while others exhibited numerous chromocenters disseminated in the nucleoplasm where nucleolei could hardly be distinguished. By contrast Juv as well as IVJ and IVM SAM nuclei appeared more evenly and lightly stained and could show clearly distinguishable darker nucleolei possibly surrounded by less abundant chromocenters. 


\section{Introduction}

During their ontogenetical development from seed germination, plants undergo successive maturational phases. These phases have been classically and chronologically referred to as (i) the juvenile phase, (ii) the mature or adult phase which begins with the formation of the reproductive organs, and (iii) the senescent phase, prelude to the death of the individual (Doorenbos 1965; Hackett 1983; 1985). They can be associated to various changes of varying intensity according to species, such as decline or even loss of ability for adventitious rooting and true-to-type cloning, production of flowers and fruits, which reflect age-related physiological influence (Robbins 1957; Robinson and Wareing 1969). This phenomenon has been referred to as phase change or physiological ageing (Schaffalitzky de Muckadell 1959; Borchert 1976). It is reversible, as demonstrated by several cases of reversions from mature to more juvenile characteristics, or rejuvenations, reported for various species (Hackett 1985, Greenwood 1987; Monteuuis et al. 2011). Phase change has focused a particular attention for a long time especially in tree species due to their huge size and long life span (Schaffalitzky de Muckadell 1959; Romberger 1963; Robinson and Wareing 1969). At the shoot apical meristem, or SAMs, level, it has been assumed to induce the formation of the reproductive organs or modifications of leaf morphology and phyllotaxy during the ontogenetical development (Passecker 1947; Schaffalitzky de Muckadell 1959). These morphological changes are particularly noticeable in heteroblastic species (Schaffalitzky de Muckadell 1959; Doorenbos 1965; Zotz et al. 2011). However, so far the influence of phase change at SAM level in relation to heteroblasty remains poorly documented (Jones 1999; Zotz et al 2011).

Choosing Acacia mangium Willd. as experimental material for studying this topic lies on several reasons. This legume tree species, widely used for re-afforesting degraded soils under the humid tropics thanks to its natural nitrogen-fixing ability, is heteroblastic (Kaplan 1980; Fig. 1). In natural environment, the young seedlings produce exclusively compound leaves with leaflets up to the $6^{\text {th }}$ or $7^{\text {th }}$ leaf, before the appearance of an intermediate leaf 
type consisting of a phyllode with four then two leaflets at its tips (Leroy and Heuret 2008). This intermediate leaf type becomes a full phyllode from the $9^{\text {th }}$ to $11^{\text {th }}$ node position upward and roughly 12 to 16 weeks after germination, depending on local conditions (Rufelds 1988; Leroy and Heuret 2008). From that age onwards, A. mangium seedlings produce phyllodes exclusively, that characterize the mature phase. Similarly to many species, this mature phase is associated to a rapid decrease in the capacity to produce adventitious roots (Darus 1993; Poupard et al. 1994; Monteuuis et al. 1995). The species can be cultivated in in vitro conditions where the mature-like microshoots with phyllodes are liable to produce compound leaves (Fig 1). However the various experiments carried out so far have failed to show any clear relationship between leaf morphology considered as a phase change marker and DNA methylation (Baurens et al. 2004; Monteuuis et al. 2009) or in vitro capacities for multiplication and adventitious rooting (Monteuuis 2004a and b).

These different reasons prompted us to examine the influence of heteroblasty on SAM characteristics of Acacia mangium in natural and in vitro conditions. Besides, such a study will also enrich our knowledge on SAM of Angiosperm tree species, as well as on the possible effects of tissue culture on SAM features.

\section{Materials and methods}

\section{Plant material}

SAM characteristics of four distinct sources of actively growing Acacia mangium below were compared. These sources were:

1. "Mat": shoots collected in April from the periphery of the crown of a 3 year-old and $10 \mathrm{~m}$ tall individual growing in natural conditions in Sabah, East Malaysia. This tree was bearing phyllodes exclusively with a spiral phyllotaxy index of $3 / 8$ and had already entered the flowering stage (Leroy and Heuret 2008). It was therefore physiologically mature (Hackett 1983). 
2. "Juv": shoots collected at the same time as the "Mat" material but from 5 to 10 $\mathrm{cm}$ tall and 2 to 3 month-old seedlings growing in the close vicinity and bearing exclusively compound leaves with a spiral phyllotaxy index of 2/5 (Leroy and Heuret 2008). This constituted the juvenile material.

3. "IVM": mature-like microshoots, initially derived from a 7 yr-old Acacia mangium (Monteuuis 2004a) and kept cultivated in vitro for 12 years on a the multiplication medium according to the procedure described in Monteuuis (2004a and $b$ ). These microshoots had started to produce phyllodes when they were collected (Fig 1).

4. "IVJ": juvenile-like microshoots of the same clonal origin and maintained in the same conditions as "IVM", but producing compound leaves consisting of leaflets instead of phyllodes when they were collected (Fig 1).

These four sources corresponded in fact to the combinations of the two basic experimental factors analyzed in this study:

(i) environment, distinguishing between natural, represented by Mat and Juv, and in vitro, represented by IVM and IVJ, conditions;

(ii) heteroblasty, differentiating compound leaves, represented by Juv and IVJ, and phyllodes, represented by Mat and IVM.

\section{Preparation for microscopic observations}

Just after collection, the 5 to $10 \mathrm{~mm}$ long shoot apices of each origin of plant materials were fixed for $48 \mathrm{~h}$ in $100 \mathrm{mM}$ phosphate buffer at $\mathrm{pH} 7.2$, supplemented with $1 \%(\mathrm{v} / \mathrm{v})$ glutaraldehyde, $2 \%(\mathrm{v} / \mathrm{v})$ paraformaldehyde, $1 \%(\mathrm{w} / \mathrm{v})$ caffeine, at room temperature (Schwendiman et al. 1988). After fixation, samples were rinsed during 1 hour in a $10 \mathrm{mM}$, phosphate buffered saline (PBS), pH 7.2, then dehydrated by successive immersions of 1 hour-duration each in graded solvent series of ethanol, from $50 \%$ to $100 \%$. Embedding in Technovit 7100 resin (Heraeus Kulzer) was performed according to manufacturer's recommendations. Longitudinal sections of the apices were cut at $2.5 \mu \mathrm{m}$ thick in series with 
glass knives using a Leica RM2065 rotary microtome (Leica, Germany). Collected sections were double stained according to Buffard-Morel et al. (1992) and Fisher (1968). Briefly, polysaccharides were stained in dark pink with periodic acid Schiff (PAS, Sigma ref. 3952016) and soluble proteins were stained in blue with naphtol blue-black (NBB, Sigma ref. 195243). Sections were then mounted in isomount-mounting medium (Labonord ref 05547535). Slides were observed with a microscope Leica DM6000 (Leica, Germany) under bright field. The more median longitudinal section of each SAM was selected for the analyses, each plant material origin being represented by thirty SAMs. Pictures were taken with a Retiga 2000R camera (Q Imaging Co.) and images were processed through Volocity 4.0.1 (Improvision, Lexington, MA, USA).

\section{Data collection and processing}

For each of these longitudinal sections, the height " $\mathrm{H}$ " and the diameter " $\mathrm{D}$ " of the apical dome were measured with the Image $\mathrm{J}$ software (Abramoff et al. 2004). $\mathrm{H}$ corresponded to distance from the distal tip of the dome to an imaginary line running perpendicular to the longitudinal axis of the shoot and originating at the point of insertion of the highest visible primordium to determine $D$, as depicted in Fig. 2 .

The first approach consisted in comparing $H, D$ and the ratio $H / D$ of the longitudinal median sections for each of the thirty SAMs per origin.

The second step consisted in sampling each of the SAM dome outline defined previously in an orthonormal axis system by 170 to 180 couples of $(x, y)$ data using the Image J software (Abramoff et al. 2004). SAM shape was classically pictured as a dome (Schüepp 1966). In addition to height $H$ and radius $R(R=D / 2)$, a shape index $S$ was estimated for a better characterization of the bulged aspect of the dome based on the following superellipse equation:

$$
\left(\frac{x}{R}\right)^{S}+\left(\frac{y}{H}\right)^{S}=1
$$


This approach was inspired by the work of Cescatti (1997) concerning crown shape of trees. With $S=2$, the shape is a classical ellipsis (and a circle if $H=R$ ). $S>1, S=1$ and $S<1$ correspond respectively to convex, flat and concave shapes. For each SAM, the superellipse parameters $\mathrm{R}, \mathrm{H}$ and $\mathrm{S}$ were estimated using the least square method (see Bates and Watts (1988) for a general reference about nonlinear regression). This was performed using the scientific library for Python, SciPy (SciPy 2008). For each apex origin the median estimated shape (i.e. the most central one within the group) was extracted on the basis of the ranking of the estimated shapes along regularly spaced directions originating from the dome centre. Possible redundancy between $\mathrm{H}, \mathrm{R}$ and $\mathrm{S}$ was assessed by principal component analysis (PCA) using the R software base package ( $\mathrm{R}$ Development Core Team 2008). As this analysis established that $H$ and $R$ were strongly correlated (0.89), $H$ and $S$ only were considered for the further multivariate analysis treatments.

At the histocytological level, preliminary observations indicated that our plant material SAMs can be divided into five distinct histocytological zones, consistently with what has been described in most Angiosperms and Gymnosperms (Buvat 1955; Romberger 1963; Medford 1992). These zones are: L1 and L2 tunica layers characterized by anticlinal cell divisions, the central mother cell zone $\mathrm{CMC}$, the peripheral zones $\mathrm{PZ}$, and the rib meristem $\mathrm{RM}$, as depicted for our experimental plant material in Fig. 2. 4ZC corresponds to L1, L2, CMC and PZ combined or to the whole SAM dome. In addition, Ho represents the distance between the origin of the rib meristem and the distal tip of SAM dome.

The experimental criteria assessed were: (i) Ho, (ii) the size of the five zones L1, L2, CMC, PZ and 4ZC defined previously and in Fig. 3, (iii) the proportion of the total area occupied by cell vacuome for each of these five zones, (iv) the number of cells in each of the same five zones, $(v)$ the measured cell area $(\mathrm{CA}),(\mathrm{vi})$ the measured nuclear area (NA), and (vii) the relevant nucleoplasmic ratio (NPR) calculated by dividing NA by (CA-NA). Actual measurement of cells showing clearly their nuclei, also measured for calculating the nucleoplasmic ratio, seemed objectively more reliable, accurate and biologically realistic than simply dividing the total area of a given zone by the number of cells recorded within the same 
zone. All the measurements were made with the Image $\mathrm{J}$ software (Abramoff et al. 2004). For accuracy and reliability reasons, only the clearer cells were randomly selected for CA, NA and NPR analyses in L1, L2 and CMC SAM zones.

The data recorded were statistically analysed by analysis of variance (ANOVA) using the SAS software (SAS Institute, Inc. 2000) "proc GLM" programs. The influence of the environment and heteroblasty, as well as of their interaction on the various criteria observed was assessed by a two ways ANOVA. Then the effect of the four origins of SAMs $(\mathrm{N}=30$ per origin) was analysed by one way ANOVA (Sokal and Rohlf 1995). Duncan's Multiple Range Test was used to differentiate means within significant treatments i.e. P-value $P \leq 0.05$ (SAS Institute, Inc. 2000; Sokal and Rohlf 1995). In a second step, bootstrap-based randomized tests (Good 2005) were used for assessing the effect of the treatments on $\mathrm{H}$ and $\mathrm{S}$ simultaneously. Their separate analyses by successive ANOVAs did not allow deducing a global $p$-value from the $p$-value of each test. These were replaced by a single test based on the ratio of inertia, defined as follows. Let $N$ be the number of individuals (i.e. SAM domes) and $N_{k}$ the number of individuals for a given origin $k$ of plant material $(1 \leq k \leq 4)$. Let $x_{i}$ be the vector of parameters associated with individual $i$ (in our case the values of $S$ and $\mathrm{H}$ for $i^{\text {th }}$ SAM), $m_{k}$ the mean vector for individuals in origin $k$ (i.e. the mean of $x_{i}$ in origin $k$ ), and $m$ the mean vector for all individuals (regardless of their origin). This statistic is defined as $\delta=|C| / T I, \quad$ where $I C I=\frac{1}{N} \sum_{k} N_{k}\left\|m_{k}-m\right\|^{2}, \quad$ called inter-origin inertia, represents the dispersion between mean vectors representing the different origins and $T I=\frac{1}{N} \sum_{i}\left\|x_{i}-m\right\|^{2}$, called total inertia, represents the total dispersion between all individuals. The ratio of inertia is a generalization of the test statistic of ANOVA, used in both factorial discriminant analysis and multivariate analysis of variance, or MANOVA (Tabachnick and Fidell 2007), to quantify the separation between origins in multivariate settings. Values of $\delta$ far from 0 indicate a good separation between origins. 
The robustness of the MANOVA-like parametric statistical tests on $\delta$ was improved using the following randomized test:

A. Compute the value $\delta_{\text {ref }}$ of $\delta$ for the true dataset (individual with non-random origins).

B. Assign random origins to individuals, such that the number of individuals of each origin is preserved (assignment does not depend on the $x_{i}$ ).

C. Compute the ratio of inertia $\delta$ using the origins obtained at step B.

Random permutations of the individuals were used for assigning random origins to individuals in adequate proportions. Steps B and C were repeated $n_{r}$ times (with $n_{r}=5000$ ). The proportion $\mathrm{P}$ of values $\delta_{\text {ref }}<\delta$ was computed, and interpreted as usual $\mathrm{p}$-values in hypothesis testing. Our approach was as described in Bertheau et al (2009). The tests used in this paper were carried out using the base package of the $R$ software ( $R$ Development Core Team 2008).

This analysis was refined by using a clustering based on a Gaussian mixture model built with the first two principal components of the PCA. The model parameters were estimated by maximum likelihood. The number of clusters was selected using the Bayesian Information Criterion, or BIC (McLachlan and Peel 2000). This was expected to provide some insight on potential clusters formed by the data. Moreover, the $\delta$ value corresponding to the clusters obtained with $\mathrm{S}$ and $\mathrm{H}$ variables was computed and used as reference for the range of variation of $\delta_{\text {ref. }}$

\section{Results}

\section{Dome shape}

SAM domes of the four origins of Acacia mangium assessed ranged from $3.9 \mu \mathrm{m}$ (Juv origin) to $66.4 \mu \mathrm{m}$ (Mat origin) in height $\mathrm{H}$, for $40.0 \mu \mathrm{m}$ (Juv origin) to $193.2 \mu \mathrm{m}$ (Mat origin) in basal diameter $D$, with $H=27.3 \mu \mathrm{m}$ and $D=97.2 \mu \mathrm{m}$ as average values. The two-way analysis of variance showed that these data and the ratio H/D were more influenced by the environment $(P=0.003$ for $H, P=0.0260$ for $D$ and $P=0.0107$ for the $H / D)$ than by 
heteroblasty which induced a significant effect $(P<0.0001)$ on $D$ only. These findings are detailed in Fig. 3 for the four origins of plant material which had a stronger effect on $\mathrm{H}$ and $\mathrm{D}$ $(P=0.0020$ for $H, P<0.0001$ for $D)$, than on the ratio $H / D(P=0.0710)$. SAMs collected from the mature trees Mat were markedly taller than those from the Juv source exposed to the same outdoor conditions, and wider than the SAMs from the two in vitro origins "IVM" and "IVJ", which could not be statistically differentiated for the same $\mathrm{H}$ and D criteria.

The median superellipses for the four SAM origins are illustrated in Fig. 4. The shape index $S(P=0.0076), H(P=0.0038)$ and $R=D / 2(P<0.0001)$ varied significantly according to SAM origins, consistently with the results observed for $H$ and $D$ measured values. Mat SAMs were statistically bigger than Juv, IVJ and IVM ones, whereas $S$ value analyses indicated that only "Mat" and "IVM" SAMs differed significantly in shape (Fig. 5). The two-way analysis of variance established that $H(P=0.0062)$ and also $R(P=0.003)$ were significantly influenced by the environment, with respective average values of $33.9 \mu \mathrm{m}$ and $51.8 \mu \mathrm{m}$ for natural vs $25.8 \mu \mathrm{m}$ and $44.6 \mu \mathrm{m}$ for in vitro conditions. Only $R$ varied markedly $(P=0.0001)$ according to heteroblasty, SAMs producing phyllodes being overall wider than those giving rise to compound leaves, regardless of the environment $(52.8 \mu \mathrm{m}$ vs $43.6 \mu \mathrm{m}$ as respective $R$ average values).

More advanced principal component analyses (PCA) indicated that two axes were sufficient to preserve $97 \%$ of the total inertia. The first of these axes corresponded to the highly correlated $\mathrm{H}$ and $\mathrm{R}$ variables, and the second axis to $\mathrm{S}$ variable, less correlated with $\mathrm{H}$ and $\mathrm{R}$ (Fig. 6).

The randomized test on the ratio of inertia for $S$ and $\mathrm{H}$ applied to the four origins of SAMs combined indicated a significant effect of plant origin jointly on $\mathrm{S}$ and $\mathrm{H}$, with a $\delta_{\text {ref }}$ value of $0.11(P=0.003) . H$ and $S$ mean values suggested that Mat differed significantly from the three other SAM origins, these latter being not statistically different. This was confirmed by the same randomized test on $\delta$ restricted to Juv, IVJ and IVM SAM origins ( $P=0.331)$.

BIC-driven cluster analysis gave rise to a 2-cluster Gaussian mixture model, indicating that the SAM population could be partitioned into two main clusters, primarily 
determined by $\mathrm{H}$ and secondarily by $\mathrm{S}$. SAMs from cluster 1 had higher $\mathrm{H}$ values than SAMs from cluster 2. None of these two clusters could be clearly associated to a specific SAM origin, although cluster 1 contained mostly Mat SAMs. A partition $\delta$ value of 0.474 suggested the $\delta$ value associated with plant origins was a priori likely to vary between 0 and approximately 0.47 .

\section{Histocytological characteristics}

The distance Ho between SAM summit and the origin of the rib meristem differed greatly $(\mathrm{P}<$ 0.0001 ) according to the four origins of SAMs investigated, with significantly higher values for Mat $(\mathrm{Ho}=35.2 \mu \mathrm{m})$ than for Juv $(\mathrm{Ho}=31.5 \mu \mathrm{m})$ and also than for the two in vitro sources IVM $(\mathrm{Ho}=25.5 \mu \mathrm{m})$ and IVJ $(24.2 \mu \mathrm{m})$. These latter, although showing the same trend as between Mat and Juv SAMs, could not be statistically differentiated in this respect. The twoway ANOVA showed that Ho was more influenced by the environment $(P<0.0001)$ than by heteroblasty $(P=0.0012)$.

The central mother cells CMC $(P=0.0003)$, the peripheral zone $P Z(P=0.049)$ and the whole SAM area 4ZC $(P=0.0008)$ were influenced with varying intensity by heteroblasty, whereas the environments had a significant influence $(P=0.0016)$ on $C M C$ area only. The relevant statistical analyses revealed strong interactions between these two factors, which could account for the differences between origins illustrated in Fig. 7. More particularly, Mat SAMs were characterised by larger L1, CMC and 4ZC areas, and Juv SAMs by a noticeably smaller PZ size than the other SAM sources. The significant influences of heteroblasty $(\mathrm{P}<$ $0.0003)$ and environment $(P<0.0003$ except for $P Z, P=0.7728)$ on the number of cells recorded may result from the much higher scores obtained for Mat SAMs compared to the other SAM origins, particularly in L1, L2, CMC and 4ZC, as suggested by Fig. 8 and the interaction $(P<0.0059)$ between heteroblasty and environment.

The two ways ANOVA indicated that the overall proportion of vacuome within each SAM zone varied greatly according to the environment $(P<0.0001$ for $L 1, C M C, P Z$ and 
4ZC, and $P=0.0004$ for L2), with higher values for SAMs coming from in vitro than from natural conditions. Heteroblasty by contrast did not induce any significant difference of vacuolization except for $L 2(P=0.0177)$ with a larger vacuome for SAMs producing phyllodes $(21.6 \%)$ than for those giving rise to compound leaves $(17.0 \%)$. Noticeable environment $X$ heteroblasty interactions $(P<0.0018)$ warrant to distinguish the four SAM origins for observing that L1, L2 and CMC cells appeared much less vacuolized in Juv SAMs than in Mat, IVM and IVJ ones (Fig. 9). These three last origins showed similar proportions of vacuome except in $\mathrm{PZ}$ where it occupied a bigger space for IVJ than for the two outdoor origins Mat and Juv.

Heteroblasty could be associated to significant changes in size for cells of $L 1$ ( $P=$ $0.0070)$ and $L 2(P=0.0023)$ and also for nuclei of $L 1(P<0.0001), L 2(P<0.0001)$ and $P Z$ $(P=0.0105)$, with higher values for SAMs producing compound leaves (Juv and IVJ origins) compared to phyllodes (Mat and IVM origins). Only the size of PZ cells $(P=0.0005)$ and nuclei $(P<0.0001)$, and also of $C M C$ nuclei $(P=0.0251)$ varied according to the environment, with larger measurements for SAMs from in vitro conditions (IVM and IVJ). A more detailed analysis (Fig 10$)$ supported by strong interactions $(P<0.0001)$ between heteroblasty and environment for most of the zones assessed indicated that the heteroblasty-induced differences in size were more salient in natural than in in vitro conditions. Juv SAMs were characterized by larger cells and nuclei for L1 and L2, whereas Mat SAMs showed smaller nuclear areas for L1, L2, CMC and PZ. The resulting nucleoplasmic ratio NPR varied with heteroblasty for $L 1(0.0016)$ and $P Z(P=0.0003)$ cells, whereas the influence of the environment on the same NPR values was significant only for CMC $(P=0.0139)$ and $P Z(P=0.0085)$ cells. The marked interactions found $(P<0.0234)$ and the analysis of the four SAMs origins considered separately (Fig 11) established for this criterion also that heteroblasty had a greater influence in natural than in in vitro conditions. Mat SAMs differed markedly from the other sources by much lower NPR values for the four SAM zones, whereas the differences were more ambiguous and inconsistent between IVM and IVJ SAMs. 
More qualitative observations (Fig 12) revealed that cells were far more vacuolized in Mat and also in IVJ and IVM SAMs than in Juv ones. Mat SAM nuclei were smaller, some of them being densely stained by NBB while the others exhibited numerous dark clusters identified as chromocenters (Fransz 2008) and disseminated in the nucleoplasm where nucleolei could hardly be distinguished. By contrast, Juv SAM nuclei were more evenly and lightly stained by NBB. Some showed clearly distinguishable darker nucleolei, possibly surrounded by much smaller and less abundant chromocenters diffused in the nuclear area. Nuclei from Juv and in vitro SAMs looked overall similar, without conspicuous difference at this level between IVJ and IVM origins. Starch granules intensively stained in pink by PAS could be seen in the hyaloplasm of some cells, irrespective of SAM origin.

\section{Discussion}

\section{Procedures for characterizing SAM dome shape}

This is the first time to our knowledge that SAMs of Acacia mangium are depicted in relation to heteroblasty in natural and in vitro conditions. One originality of our study compared to previous ones (Tepper 1963; Owston 1969; Gifford and Corson 1971) has been to refine the characterization of SAM morphology by determining a shape index S. Proper statistical approaches established that this index $S$ could vary independently from the more classically used $\mathrm{H}$ and $\mathrm{D}$ variables. Also, the relevant $\mathrm{p}$-value was inferior when the randomized test was applied to $\mathrm{H}$ and $\mathrm{S}$ jointly than when the ANOVAs were performed separately for $\mathrm{H}$ and S. Consequently, treatment influence on individuals characterized by $\mathrm{H}$ and $\mathrm{S}$ combined can be more accurately assessed by a single multivariate analysis than by two univariate analyses. From a more methodological point of view, such multivariate analysis overcomes the issue of combining the two p-values of independent partial analyses (Tabachnick and Fidell 2007). 


\section{Sampling considerations}

A. mangium SAMs, although slightly bigger than in $E$. urophylla $X E$. grandis (Mankessi et al. 2010) but smaller than for a lot of Gymnosperms and Angiosperms (Clowes 1961), showed the zonation pattern classically depicted in higher plants (Clowes 1961; Romberger 1963; Mankessi et al. 2011). Variations of SAM size, shape and even histocytological characteristics have been noticed between and even within various arborescent species (Parke 1959; Owston and Molder 1973; Monteuuis 1989). These differences could be caused by variations of organogenic activity or plastochron phase of the SAMs observed, as recently demonstrated in Eucalyptus urophylla x E.ucalyptus grandis (Mankessi et al. 2010; 2011). In temperate countries with highly contrasted seasonal variations of photoperiod and temperature, such within origin heterogeneity can be minimized by studying SAMs in similar physiological conditions, for instance resting or budbreak stage (Parke 1959; Owston 1969; Monteuuis 1989). This was not possible in Sabah or in vitro conditions where $A$. mangium can grow all year long under favourable conditions. Due to these reasons and for higher reliability of our observations, we decided to work on sufficiently large samples.

\section{Influence of heteroblasty on SAM characteristics outdoors}

In natural environment, Acacia spp, phyllodes are bigger than compound leaves, and likewise for the shoots tips from which these two foliar appendages derive (Kaplan 1980; Monteuuis et al. 1995). This could account for the higher morphological but also zone measurement and cell number scores recorded for Mat SAMs compared to Juv ones. These observations, in accordance with other studies on various species (Tepper 1963; Monteuuis 1989; Mankessi et al. 2010; 2011), suggest that SAM size and associated number of cells could be more influenced by the vigor of the shoot axis underneath than by heteroblasty per se. This view is supported by the fact that in in vitro conditions where such differences in size between shoots with phyllodes and shoot with compound leaves did not exist, IVJ and IVM 
SAMs looked similar, except at the nucleus level. Conversely, Mat and IVM SAMs, despite producing both phyllodes but respectively in natural and in vitro conditions, showed a lot of morphological and infrastructural differences most likely due to the greater vigor and size of the Mat origin.

Our investigations confirmed the rationale of distinguishing for each SAM origin the four zones L1, L2, CMC and PZ, with cell characteristics liable to vary according to heteroblasty. The bigger size of L1 and L2 cells and nuclei for Juv SAMs than for Mat ones could explain the (sub)epidermal differences between the fully developed compound leaves and phyllodes (Kaplan 1980; Yu and Li 2007), and also the higher resistance to hydric stress of these latter (Monteuuis et al. 1995). As logically expected, Juv SAM cells showed juvenile characteristics such high nucleoplasmic ratios and reduced vacuome, whereas Mat SAM cells exhibited mature features (Esau 1965). Kaplan (1980) also noticed for other Acacia spp in natural conditions that SAMs giving rise to phyllodes were more vacuolized than those producing compound leaves. At the nucleus level, the intensive staining and numerous chromocenters observed for the Mat SAMs could be due to a high proportion of heterochromatin. This heterochromatin, with its included proteins stained in dark blue by NBB and possibly combined to histones, has been assumed to be prone to methylation, and thus less transcriptionally active than the euchromatin (Verdeil et al. 2007; Fransz 2008). The situation looked different for Juv SAM nuclei where the fewer chromocenters and the lighter staining suggest a higher proportion of decondensed chromatin in the nucleoplasm but also in the nucleolei to regulate nucleolus activities including ribosome biogenesis (Fransz 2008; McKewon and Shaw 2009; Bártová et al. 2010). This strengthens the assumption that SAMs from juvenile material are likely transcriptionally more active than SAMs from mature material, consistently with our observations on eucalypts (Mankessi et al. 2010; 2011). Maturation might correspond also to a diminution of nucleotide and protein synthesis as well as of metabolic activity (Monteuuis and Gendraud 1987; Bon 1988). 


\section{Influence of heteroblasty on SAM characteristics in vitro}

Tissue culture has been reported to induce various kinds of changes for several plant species (George 1993; Greenwood 1987; von Aderkas and Bonga 2000).For A. mangium, it can be concluded from the comparison between Mat and the two IVM and IVJ SAM origins that in vitro culture resulted in a noticeable reduction of SAM size and cell numbers. This was also observed for Dahlia variabilis (Watelet-Gonod and Fabre 1981) and more recently for Eucalyptus urophylla $\times$ Eucalyptus grandis notwithstanding for this latter case a marked influence of the plastochron (Mankessi et al. 2010; 2011). Size reduction of shoots, compound leaves and phyllodes in in vitro conditions could account for the disappearance of the differences in size and cell numbers noticed in natural conditions between Mat and Juv SAMs. In vitro, mature selected genotypes can produce juvenile leaves, mostly from axillary buds stimulated by the trimming of the microshoots before their transfer to the next subculture cycle (Baurens et al. 2004, Monteuuis 2004a and b, Fig. 1). Morphological reversions or rejuvenations (Monteuuis et al. 2011) can also derive more symptomatically from terminal buds (Fig. 13. To date, as far as we are aware, such reversions of the mature phyllode type to the juvenile compound leaves have been noticed at the SAM level for $A$. mangium only in vitro conditions. These rejuvenations demonstrate that heteroblastic development is liable to be influenced by the environment, and can occasionally include reverse morphological changes i.e. from mature to juvenile state (Zotz et al. 2011). Such recovery of juvenile morphology, together with the morphological and infrastructural similarities noticed at the SAM and nucleus levels between the in vitro materials and Juv that can be considered a juvenile control, illustrate the apparent rejuvenating effect of tissue culture reported for different species (Fouret et al. 1986; Pierik 1990; Hammatt and Grant 1993). The increased capacity for adventitious rooting and multiplication observed for the same mature genotype (Monteuuis 2004a and b) are additional supportive arguments despite the lack of clear relationship so far between these putative indicators of ageing, leaf morphology and DNA methylation rates (Baurens et al. 2004). Conversely, some other characteristics like a large vacuome and a higher rate of methylated DNA reported for 
different species in vitro (Valledor et al. 2007; Monteuuis et al. 2009) are more representative of the mature stage. This reinforces the opinion on the particularities of in vitro plant tissues (George 1993; Mankessi et al. 2011), and on the ambiguity of the apparent rejuvenations observed in such conditions (Hackett 1985; Pierik 1990; Von Aderkas and Bonga 2000).

\section{Conclusion}

The effects of heteroblasty on SAM characteristics of $A$. mangium are liable to vary according to the environment. Outdoors, the bigger size of the phyllodes and of the shoot axis underneath, as well as the vigor may interfere. And if heteroblasty can be observed on shoot tips of similar size and vigor in tissue culture conditions, the perturbing influence of particular in vitro-induced effects should not be underestimated. These remarks and our findings encourage to focus the investigations more at the cellular and nucleus level in SAM zones where heteroblasty-related differences have been detected. Deeper analyses on chromatin and nucleolus structure and composition in relation to transcription potential may provide enlightening information of the origin of heteroblasty and its likely relationship with phase change. Recent advances on the molecular determinism of these phenomena involving microRNAs pleads for investigating further along these lines (Martin et al. 2010, Wang et al. 2011, Zotz et al. 2011).

\section{Acknowledgements}

The authors are indebted to ATP CIRAD "Méristèmes" for financial contribution to this study.

\section{References}

Abramoff MD, Magelhaes PJ, Ram SJ (2004) Image Processing with ImageJ. Biophotonics International 11, 36-42.

Bártová E, Horáková AH, Uhlírová R, Raška I, Galiová G, Orlova D, Kozubek S (2010) Structure and Epigenetics of Nucleoli in Comparison With Non-nucleolar Compartments. J Histochem Cytochem. 58, 391-403.

Baurens FC, Nicolleau J, Legavre T, Verdeil JL, Monteuuis O (2004) Genomic DNA methylation of juvenile and mature Acacia mangium micropropagated in vitro with reference to leaf morphology as a phase change marker. Tree Physiol. 24, 401-407. 
Bertheau C, Salle A, Rossi J.-P., Bankhead-Dronnet S, Pineau X, Roux-Morabito G, Lieutier $F$ (2009) Colonisation of native and exotic conifers by indigenous bark beetles (Coleoptera: Scolytinae) in France. Forest Ecology and Management 258, 1619-1628

Bon MC (1988) Nucleotide status and protein synthesis in vivo in the apices of juvenile and mature Sequoiadendron giganteum during budbreak. Physiologia Plantarum 72, 796800

Borchert R (1976) The concept of juvenility in woody plants. Acta Horticulturae 56, 57-69

Buffard-Morel J, Verdeil JL, Pannetier C (1992) Embryogenèse somatique du cocotier (Cocos nucifera L.) à partir d'explant foliaire: étude histologique. Canadian Journal of Botany 70, 735-741

Buvat R (1955) Le méristème floral de la tige. Année Biologique 31, 596-656

Cescatti A (1997) Modelling the radiative transfer in discontinuous canopies of asymmetric crown. I. model structure and algorithms. Ecological Modelling 101, 263274.

Clowes FAL (1961) "Apical meristems." (Blackwell Scientific Publications, Oxford)

Darus HA (1993) Vegetative propagation. In "Acacia mangium: growing and tilization". (Eds Kamis Awang, Taylor D) MPTS monograph series no 3, pp 59-74. (Winrock International, FAO: Bangkok, Thailand).

Doorenbos J (1965) Juvenile and adult phases in woody plants. Encycl. Plant Physiol 15, 1222-1235.

Esau K (1965) "Plant anatomy." (John Wiley \& Sons, Inc., New York, London, Sydney).

Fisher DB (1968) Protein staining of ribboned epon sections for light microscopy. Histochemie 16, 92-96

Fouret Y, Arnaud Y, Larrieu C Miginiac E (1986) Sequoia sempervirens as an in vitro rejuvenation model. New Zealand.Journal of Forest Science 16: 319-327.

Fransz P (2008) Chromatin domains and function. In "Functional Organization of the Plant Nucleus." (Ed I. Meier) pp 131-156. (Springer Verlag, New-York).

George EF (1993) "Plant propagation by tissue culture, Part 1 and 2". (Exegetics Ltd., Basingstoke, England).

Gifford EM, Corson GE (1971) The shoot apex in seed plant. The Botanical Review 37, 143229

Greenwood MS (1987): I. Rejuvenation of forest trees. Plant Growth Regulators 6, 1.12.

Hackett W P (1983) Phase change and intra-clonal variability. HortScience 18, 12-16.

Hackett WP (1985) Juvenility, maturation and rejuvenation in woody plants. Horticultural Reviews 7, 109-155.

Hammatt N, Grant NJ (1993) Apparent Rejuvenation of Mature Wild Cherry (Prunus avium L.) during micropropagation. J. Plant Physiol. 141, 341-346.

Jones CS (1999) An essay on juvenility, phase change, and heteroblasty in seed plants. International Journal of Plant Science 160, S105-S111

Kaplan SL (1980) Heteroblastic leaf development in Acacia. Morphological and morphogenetic implications. Cellule 73,137-203

Leroy C, Heuret P (2008) Modelling changes in leaf shape prior to phyllode acquisition in Acacia mangium Willd. seedlings. Comptes Rendus - Biologie 331, 127-136.

Mankessi F, Saya AR, Boudon F, Guedon Y, Montes F, Lartaud M, Verdeil JL, Monteuuis O (2010) Phase change-related variations of dome shape in Eucalyptus urophylla $\mathrm{X}$ Eucalyptus grandis shoot apical meristems. Trees 24, 743-752.

Mankessi F, Saya AR, Montes F, Lartaud M, Verdeil JL, Monteuuis O (2011) Histocytological characteristics of Eucalyptus urophylla x Eucalyptus grandis shoot apical meristems of different physiological ages. Trees (in press).

Martin RC, Asahina M, Liu PP, Kristof JR, Coppersmith JL, Pluskota WE, Bassel GW, Goloviznina NA, Nguyen TT, Martınez-Andujar C, Arun Kumar MB, Pupel P,Nonogaki $\mathrm{H}$ (2010) The microRNA156 and microRNA172 gene regulation cascades at postgerminative stages in Arabidopsis. Seed Science Research 20, 79-87

McKeown PC, Shaw PJ (2009) Chromatin: linking structure and function in the nucleolus. Chromosoma 118, 11-23 
McLachlan G, Peel D (2000) Chapter 6: Assessing the Number of Components in Mixture Models. In "Finite Mixture Models". (Eds G. McLachlan \& D. Peel) pp 175-220. (Wiley, New York).

Medford Jl (1992) Vegetative apical meristems. The Plant Cell 4, 1029-1039

Monteuuis O (1989) Analyses microscopiques de points végétatifs de Sequoiadendron giganteum jeunes et âgés durant le repos végétatif et lors du débourrement. Bulletin de la Société Botanique de France, Lettres Bot. 136 (4/5), 317-326

Monteuuis O (2004a) In vitro micropropagation and rooting of Acacia mangium microshoots from juvenile and mature origins In Vitro Cell. Dev. Biol.-Plant 40, 102-107.

Monteuuis $\mathrm{O}(2004 \mathrm{~b})$ In vitro rooting of juvenile and mature Acacia mangium microcuttings with reference to leaf morphology as a phase change marker. Trees 18 (1), 77-82.

Monteuuis O, Gendraud M (1987) Nucleotide and nucleic acid status in shoot tips from juvenile and mature clones of Sequoiadendron giganteum during rest and growth phases. Tree Physiology 3,257-263

Monteuuis O, Vallauri D, Poupard C, Chauvière M (1995) Rooting Acacia mangium cuttings of different physiological age with reference to leaf morphology as a phase change marker. Silvae Genetica 44 (2-3), 150-154

Monteuuis O, Baurens FC, Goh DKS, Quimado M, Doulbeau S, Verdeil JL (2009) DNA methylation in Acacia mangium in vitro and ex-vitro buds, in relation to their withinshoot position, age and leaf morphology of the shoots. Silvae Genetica 58 (5-6), 287292.

Monteuuis O, Lardet L, Montoro P, Berthouly M, Verdeil JL (2011). Somatic embryogenesis and phase change in trees (in press).

Owston PW (1969) The shoot apex in eastern white pine: its structure, seasonal development, and variation within the crown. Canadian Journal of Botany 47, 11811188

Owston PW, Molder M (1973) Bud development in western hemlock. I. Annual growth cycle of vegetative buds. Can. J. Bot. 51, 2223-2231.

Parke RV (1959) Growth periodicity and the shoot tip of Abies concolor. American Journal of Botany 46(2), 110-118

Passecker F (1947) Entwicklungsphasen und vegetative Vermehrung holziger Gewächse. Zbl. Ges. Forst- u. Holzw. 70 (3/4), 270-292.

Pierik RLM (1990) Rejuvenation and micropropagation. In "Progress in Plant Cellular and Molecular Biology". (Eds HJJ Nikkamp HJJ, LHW Van Der Plas, J Van Aartrijk) pp 91101. (Amsterdam, Netherlands).

Poupard C, Chauvière M, Monteuuis O (1994) Rooting Acacia mangium cuttings: Effects of age, within-shoot position and auxin treatment. Silvae Genetica, 43 (4), 226-231

R Development Core Team (2008) R: A Language and Environment for Statistical Computing. R Foundation for Statistical Computing, Vienna, Austria, ISBN 3-90005107-0, http://www.R-project.org.

Robbins WJ (1957) Physiological aspects of aging in plants. Amer. J. Bot. 44, 289- 294.

Robinson LW, Wareing PF (1969) Experiments on the juvenile-adult phase change in some woody species. New Phytologist 68, 67-78.

Romberger JA (1963) "Meristems: growth and development in woody plants". (U.S. Dep. Agr. Tech. Bull. USA).

Rufelds CW (1988) Acacia mangium, A. auriculiformis, and hybrid A. auriculiformis seedling morphology study. Forest Res. Centre, Sepilok, Sabah, East Malaysia

SAS (2000) "SAS/STAT User's Guide", Cary, NC, USA

Schaffalitzky de Muckadell M (1959) Investigations on aging of apical meristems in woody plants and its importance in silviculture. Kandrup and Wunsch's Bogtrykkeri, København, pp 313-346

Schüepp O (1966) Meristeme: Wachstum und Formbildung in den Teilungsgeweben höherer Pflanzen. (Birkhäuser verlag, Basel and Stuttgart). 
Schwendiman J, Pannetier C, Michaux-Ferriere N (1988) Histology of somatic embryogenesis from leaf explants of the oil palm Elaeis guineensis. Annals of Botany $62,43-52$

SciPy (2008) Scientific Tools for Python, SciPy Reference Guide, Enthought, http://www.scipy.org.

Sokal RR, Rohlf FJ (1995) "Biometry" (WH Freeman and Company, New York)

Tabachnick BG, Fidell LS (2007) Chapter 7: Multivariate Analysis of Variance and Covariance. In "Using Multivariate Statistics" (Eds BG Tabachnick \& LS Fidell), Fifth Edition, pp 243-310 (Boston: Pearson Education, Inc. / Allyn and Bacon. USA).

Tepper HB (1963) Dimensional and zonational variation in dormant shoot apices of Pinus ponderosa. Amer. J. Bot. 50, 589-596..

Valledor L, Hasbun R, Meijon M, Rodriguez JL, Santamaria E, Viejo M, Berdasco M, Feito I, Fraga MF, Canal MJ, Rodriguez R (2007) Involvement of DNA methylation in tree development and micropropagation. Plant Cell Tissue and Organ Culture 91, 75-86.

Verdeil JL, Alemanno L, Niemenak N, Tranbarger TJ (2007). Pluripotent versus totipotent plant stem cells: dependence versus autonomy? Trends in plant science 12, 245-252

Von Aderkas P, Bonga JM (2000) Influencing micropropagation and somatic embryogenesis by manipulation of phase change and culture environment. Tree Physiology 20, 921928.

Wang JW, Park MY, Wang LJ, Koo Y, Chen XY, Weigel D, Poethig RS (2011) MiRNA control of vegetative phase change in trees. PLoS Genetics 7(2), e1002012.

Watelet-Gonod MC, Favre JM (1981) Miniaturisation et rajeunissement chez Dahlia variabilis (variété Télévision) cultivé in vitro. Annales des Sciences Naturelles Botaniques 13, 51-67.

Yu H, Li JT (2007) Physiological comparisons of true leaves and phyllodes in Acacia mangium seedlings. Photosynthetica 45, 312-316.

Zotz G, Wilhelm K, Becker A (2011). Heteroblasty - a review. Botanical Review (in press). 


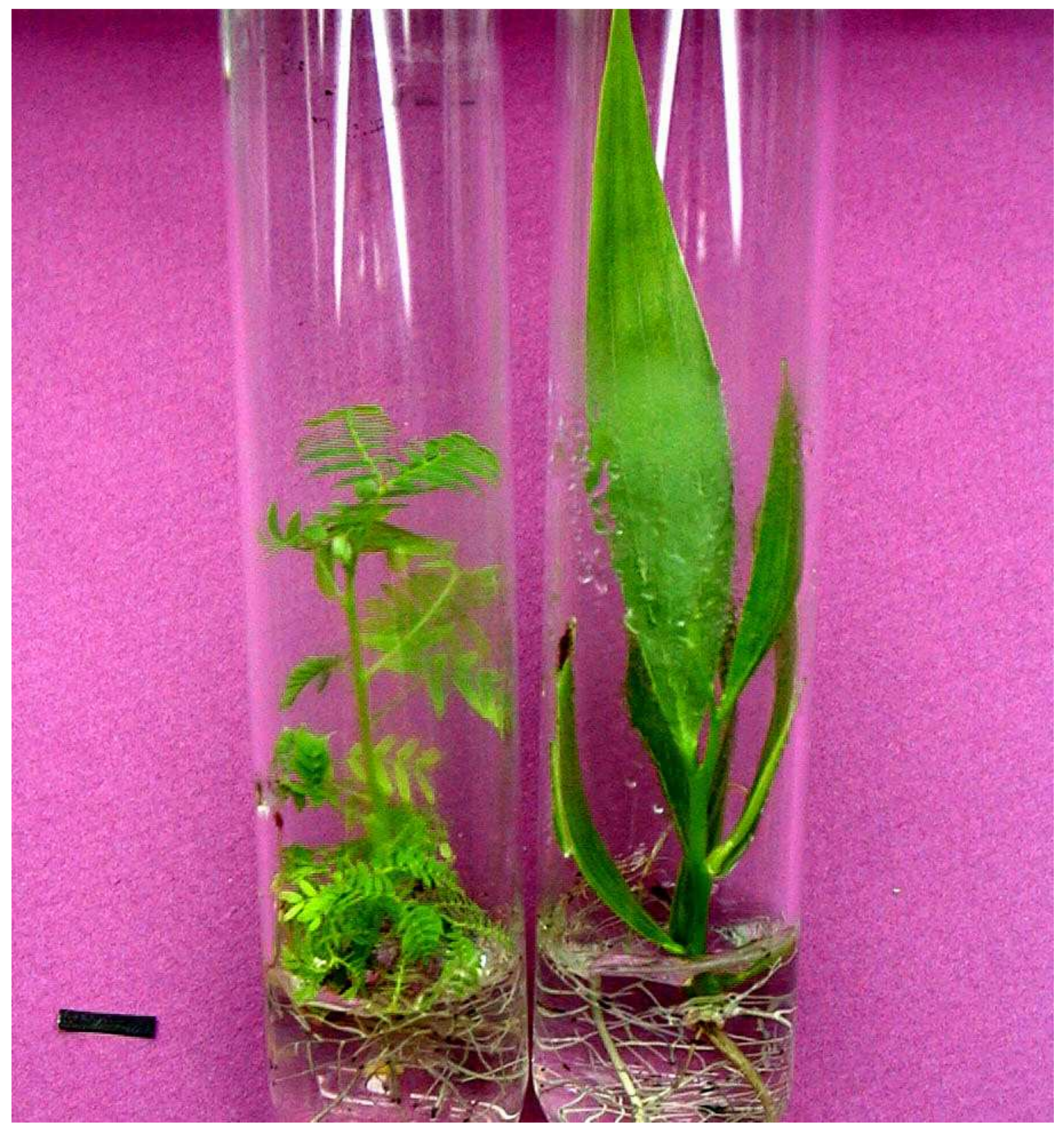

Fig. 1. Illustration of heteroblasty in in vitro microshoots derived from a mature selected Acacia mangium tree and subcultivated several years in tissue culture conditions: the juvenile type "IVJ" (left) is characterized by compound leaves consisting exclusively of leaflets, whereas the mature-like type "IVM" (right) produces phyllodes. Scale bar is $1 \mathrm{~cm}$ long. 


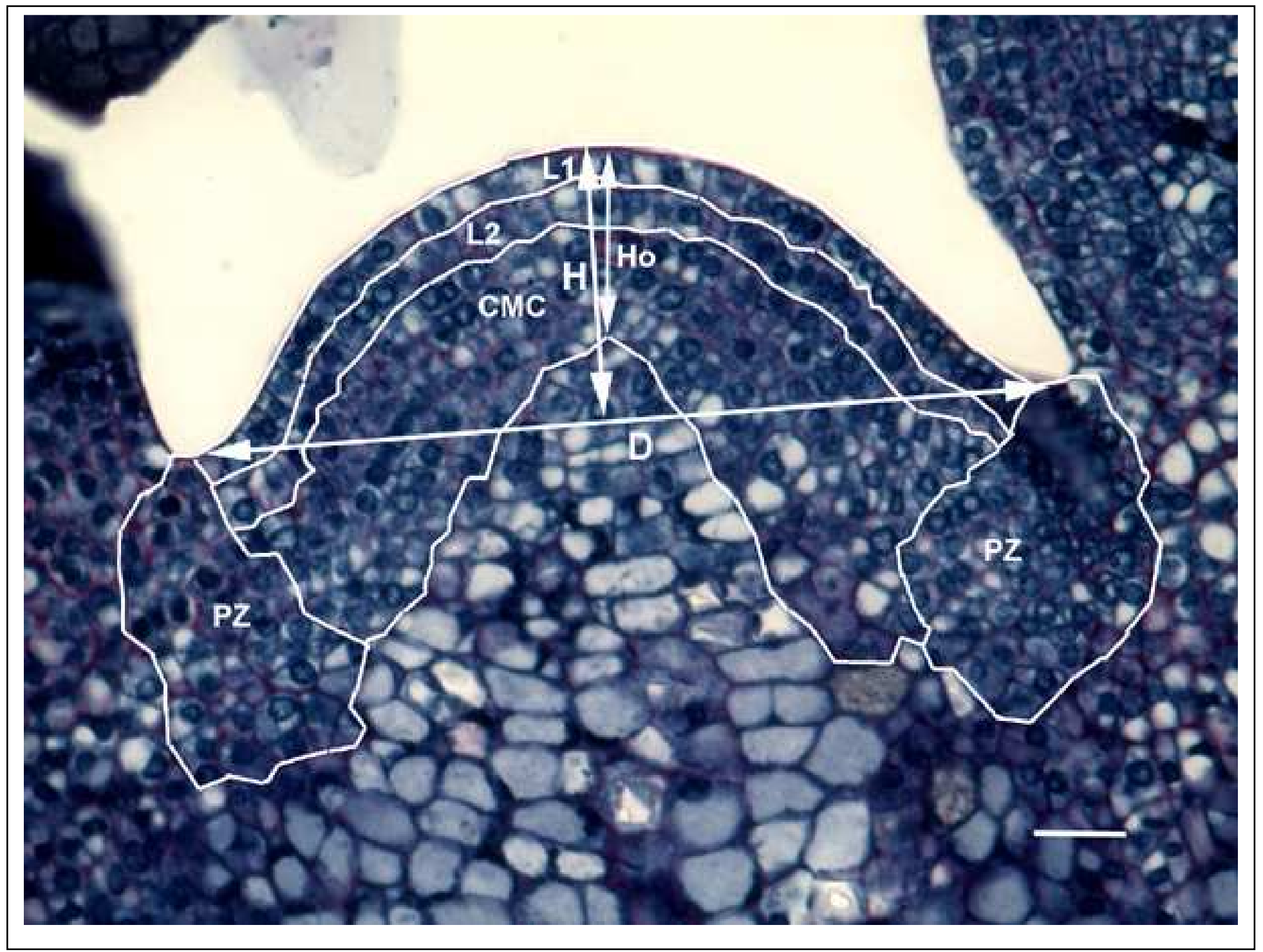

Fig. 2. Longitudinal median cross section of an Acacia mangium SAM depicting $H, D, H o$, as well as the five histocytological zones assessed i.e. L1 and L2 tunica layers, the central mother cell zone CMC, the peripheral zones PZ. Scale bar represents $20 \mu \mathrm{m}$. 


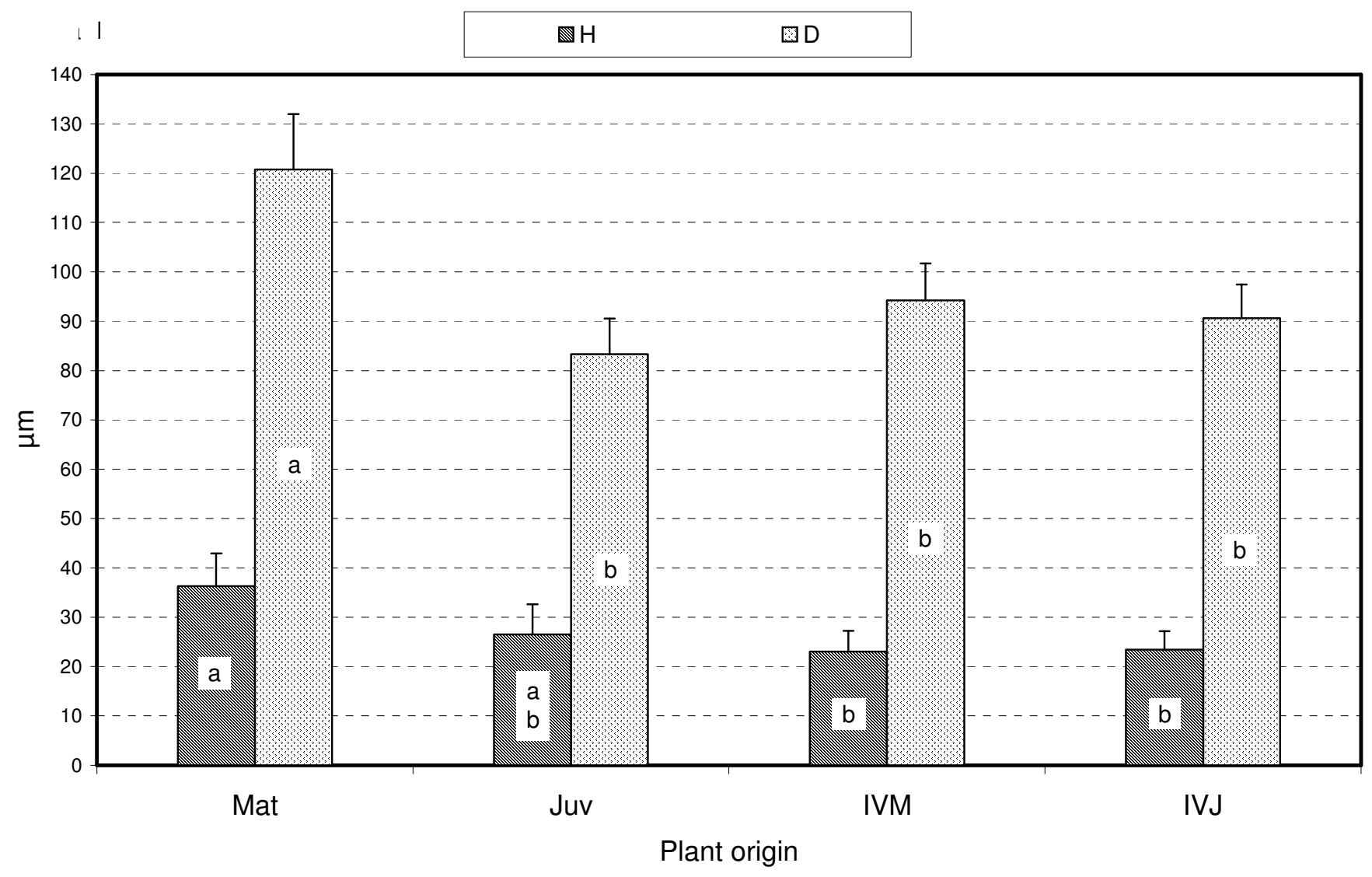

Fig. 3. Average dome heights $\mathrm{H}$ and diameters $\mathrm{D}$ of the four SAM origins assessed. Mean values were established from 30 SAM median sections observed per origin. Bars represent confidence intervals at $\mathrm{Po}=5 \%$ and different letters distinguish means which are significantly different at the same $5 \%$ level for each criterion. 


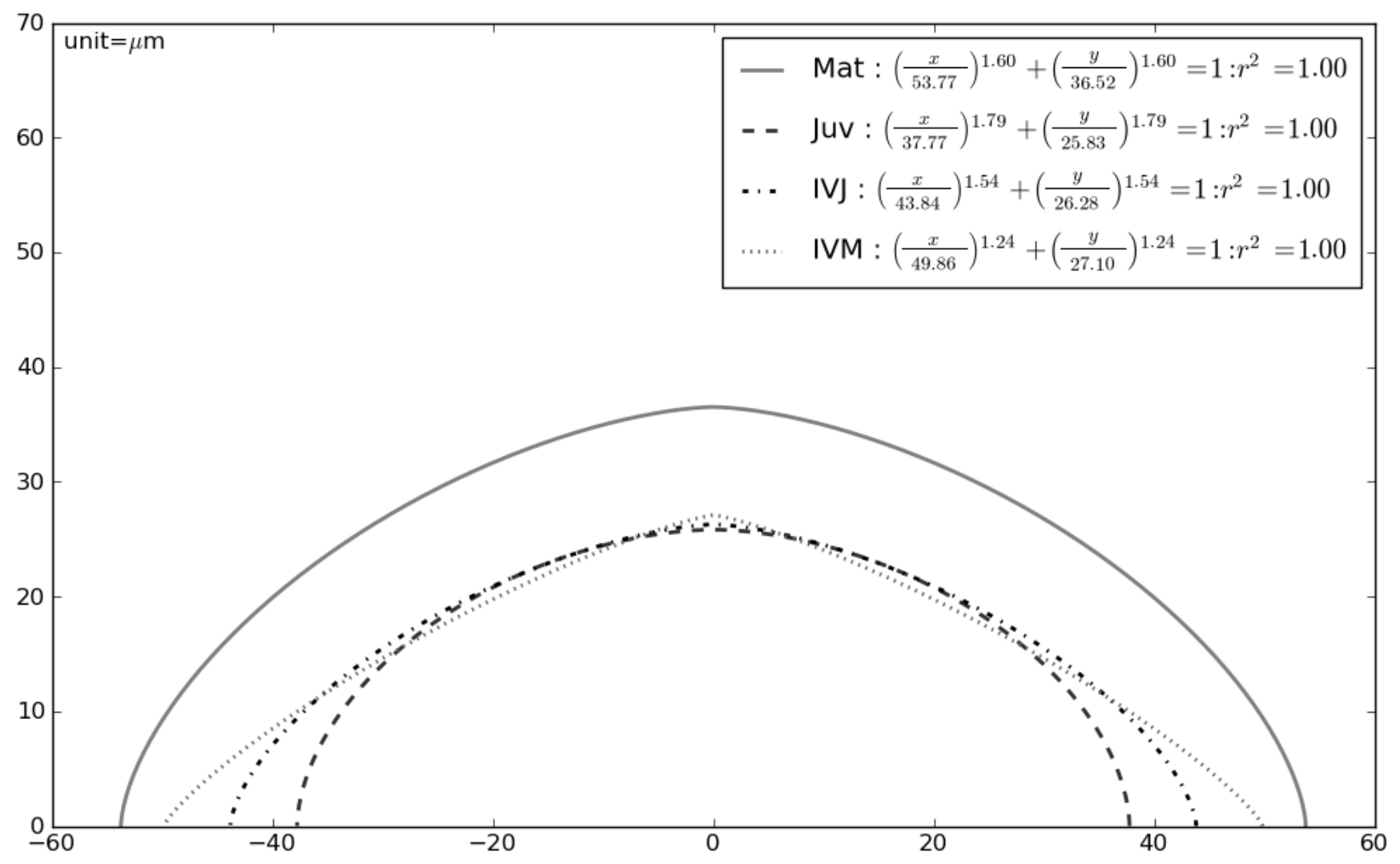

Fig. 4. Median estimated superellipse (sample size $N=30$ ) for the four origins of $S A M$ assessed, with the associated equations and coefficients of determination $r^{2}$, with all $(30 \times 4=120)$ values equal to 1, except for two $\left(r^{2}=0.97\right.$ and $\left.r^{2}=0.99\right)$ 


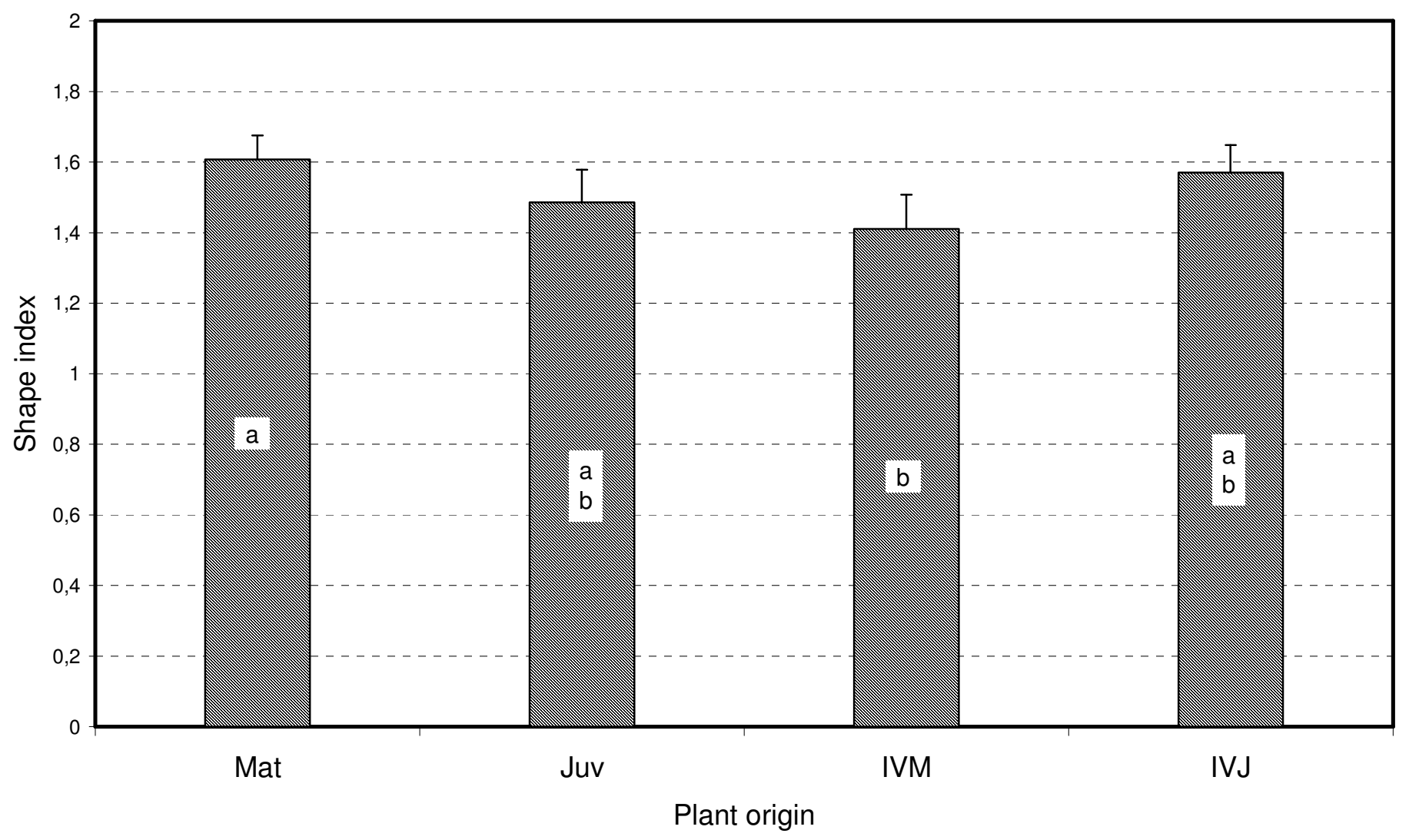

Fig.5. Average dome shape index $S$ for the four SAM origins assessed $(N=30$ observations per origin). Bars represent confidence intervals at $\mathrm{Po}=5 \%$ and different letters distinguish means which are significantly different at the same $5 \%$ level for each criterion. 


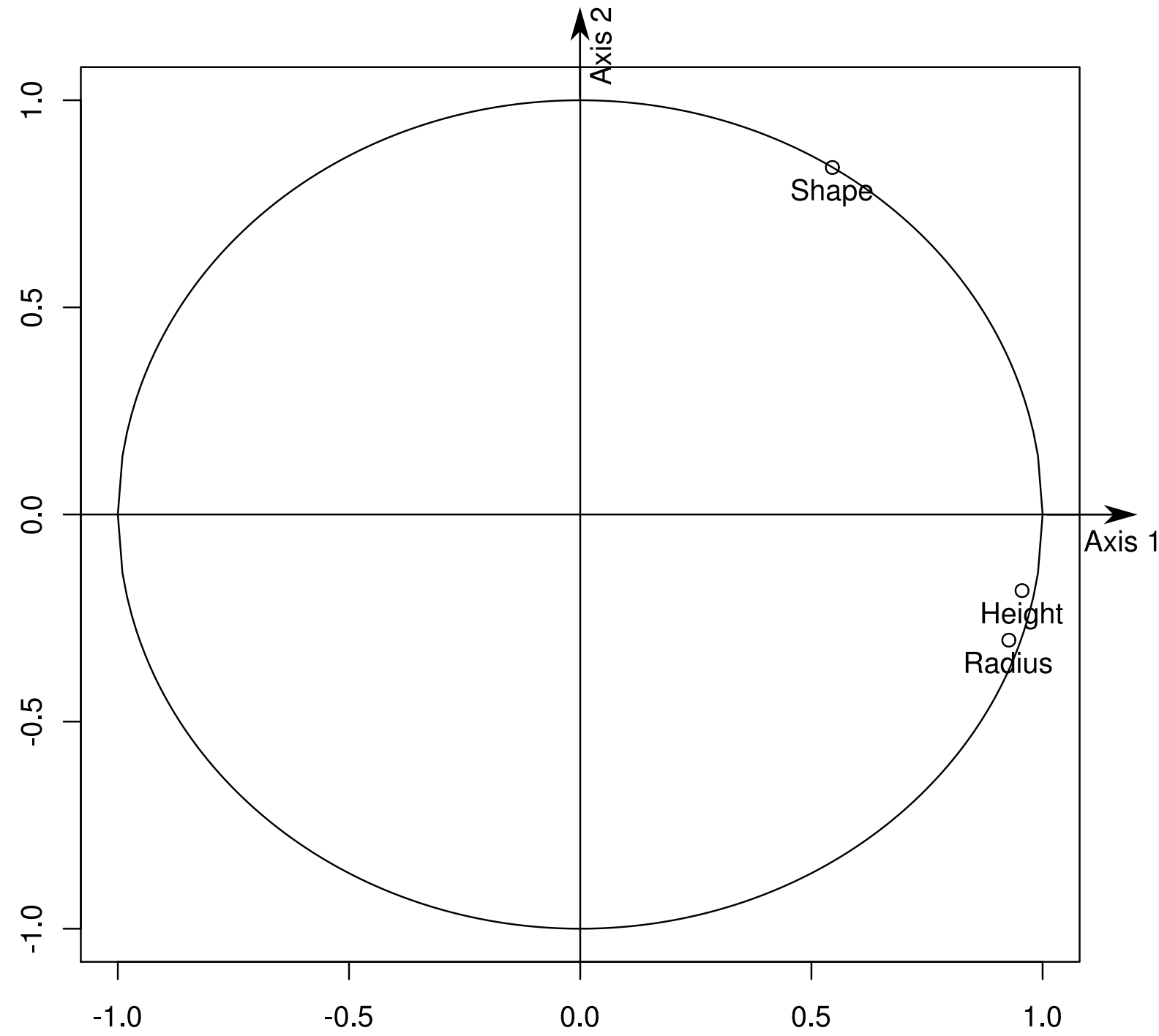

Fig. 6. Representation of the variables in the first principal plane of the PCA. This combination of axis 1 (associated with height $\mathrm{H}$ and radius $\mathrm{R}$ ) and of axis 2 (associated with shape $\mathrm{S}$ ) preserves $97 \%$ of total inertia. 


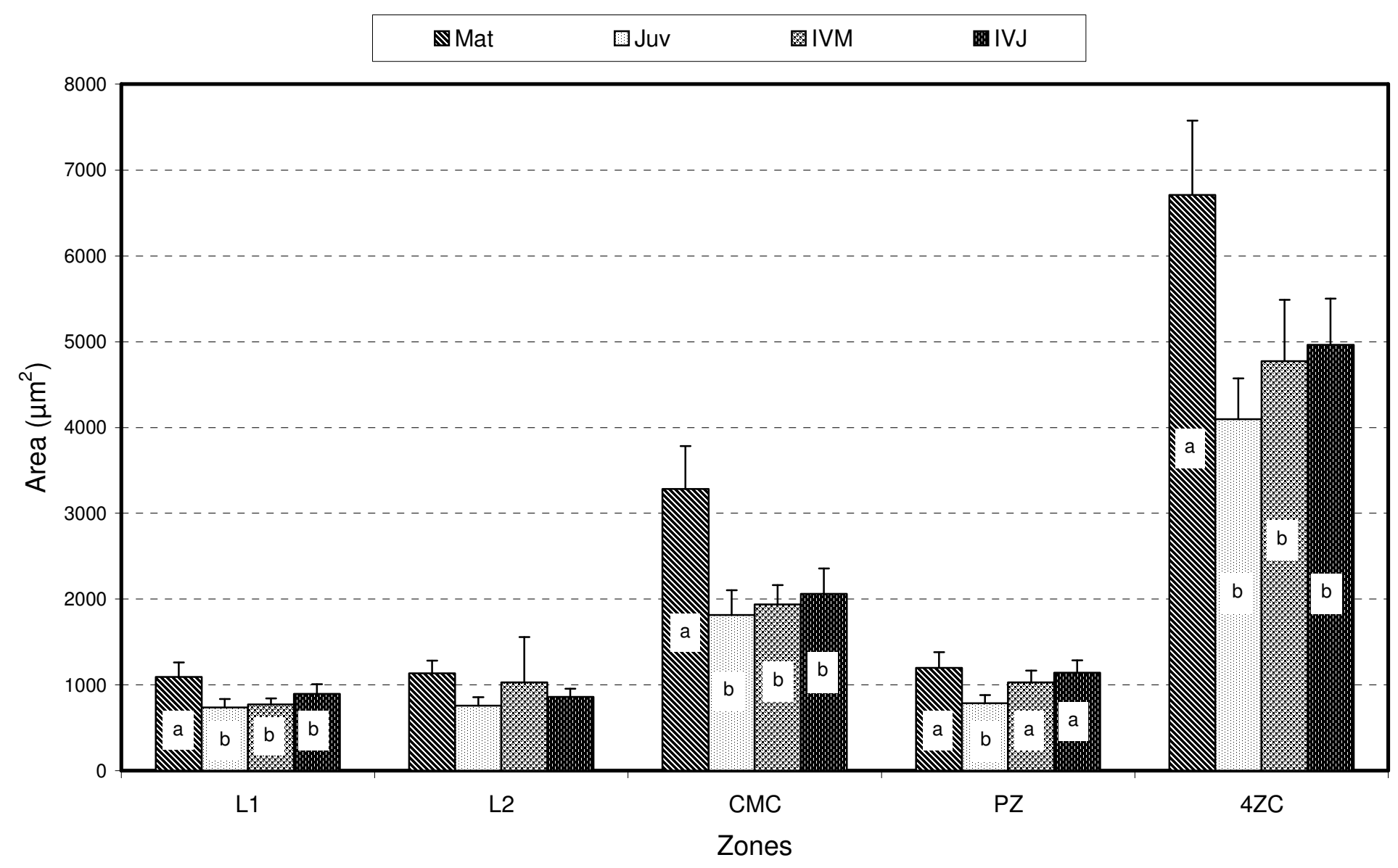

Fig. 7. Influence of the four SAM origins assessed on L1 $(P=0.0002)$, $L 2(P=0.2761), C M C$ $(P<0.0001), P Z(P=0.0017)$ and $4 Z C(P<0.0001)$ areas. Mean values were established from 30 SAM median sections observed per origin. Bars represent confidence intervals at Po $=5 \%$ and letters distinguish means which are significantly different for a given zone at the same $5 \%$ level. 


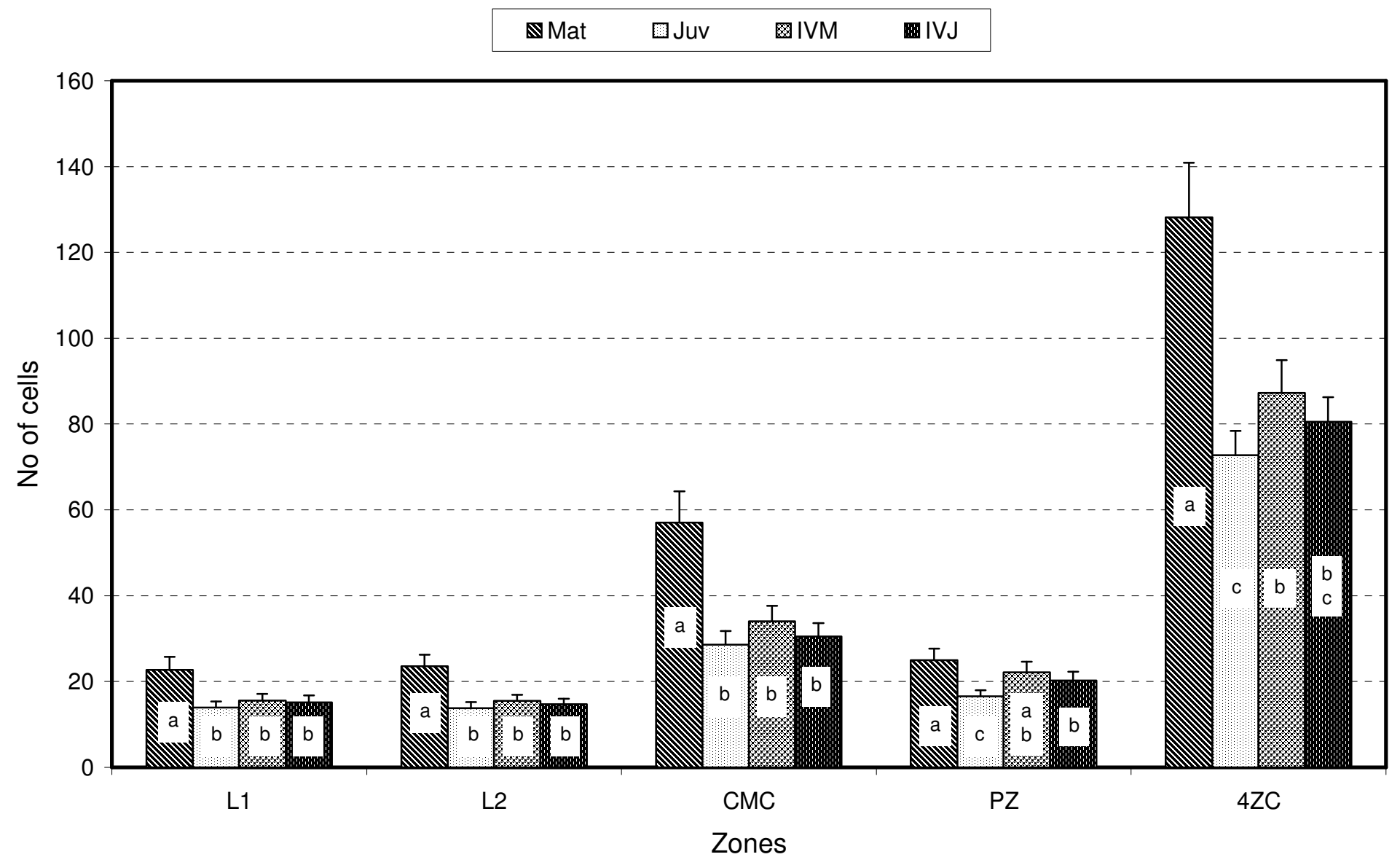

Fig. 8. Influence of the four origins assessed on the number of cells of $L 1(P<0.0001), L 2(P$ $<0.0001), \mathrm{CMC}(\mathrm{P}<0.0001), \mathrm{PZ}(\mathrm{P}<0.0001)$ and 4ZC $(\mathrm{P}<0.0001)$ areas. Mean values were established from 30 SAM median sections observed per origin. Bars represent confidence intervals at $\mathrm{Po}=5 \%$ and letters distinguish means which are significantly different for a given zone at the same $5 \%$ level. 


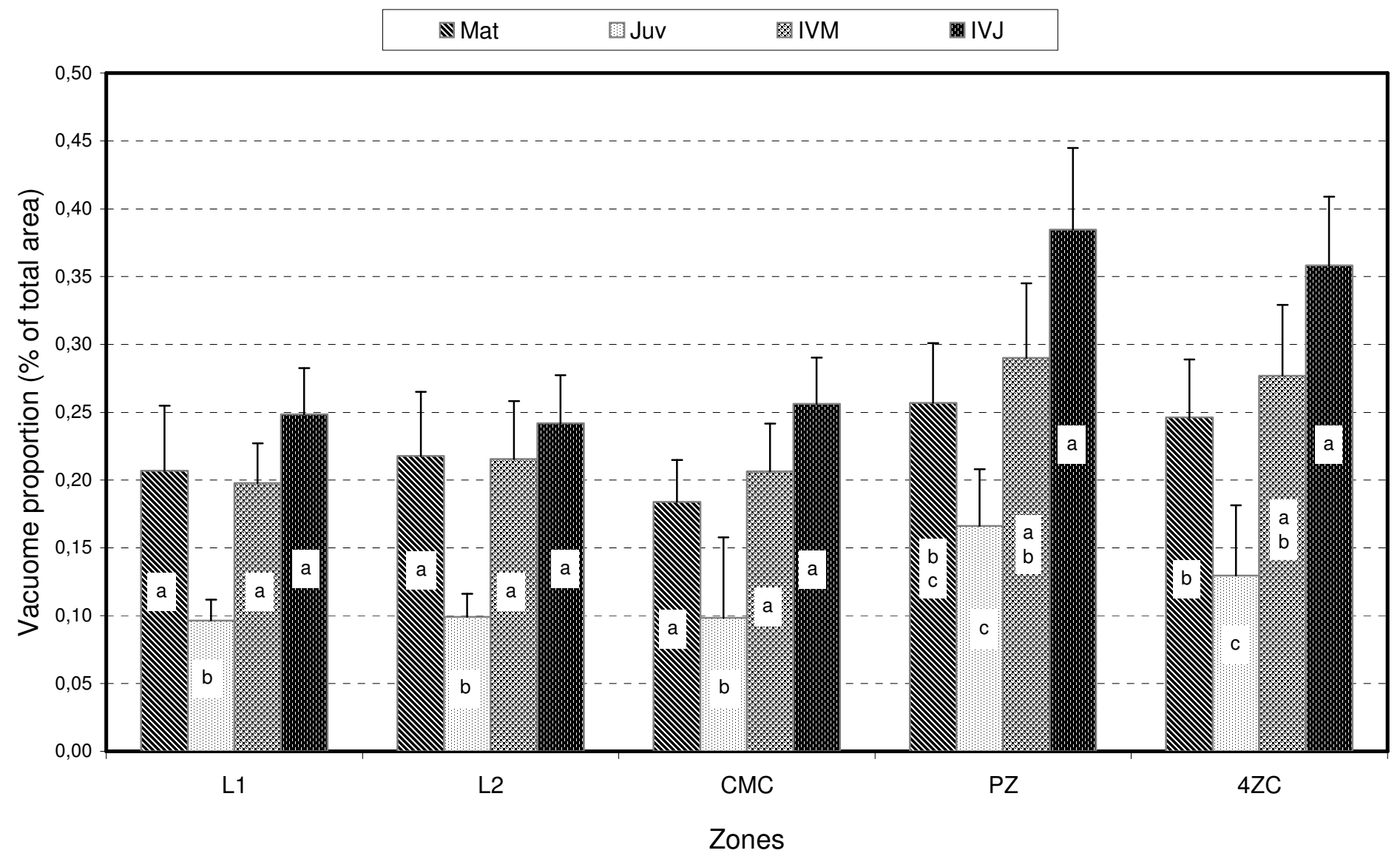

Fig. 9. Influence of the four SAM origins assessed on the proportion of total area occupied by vacuome for $L 1, L 2, C M C, P Z$, and $4 Z C(P<0.0001)$. Mean values were established from 30 SAM median sections observed per origin. Bars represent confidence intervals at Po $=5 \%$ and letters distinguish means which are significantly different for a given zone at the same $5 \%$ level. 


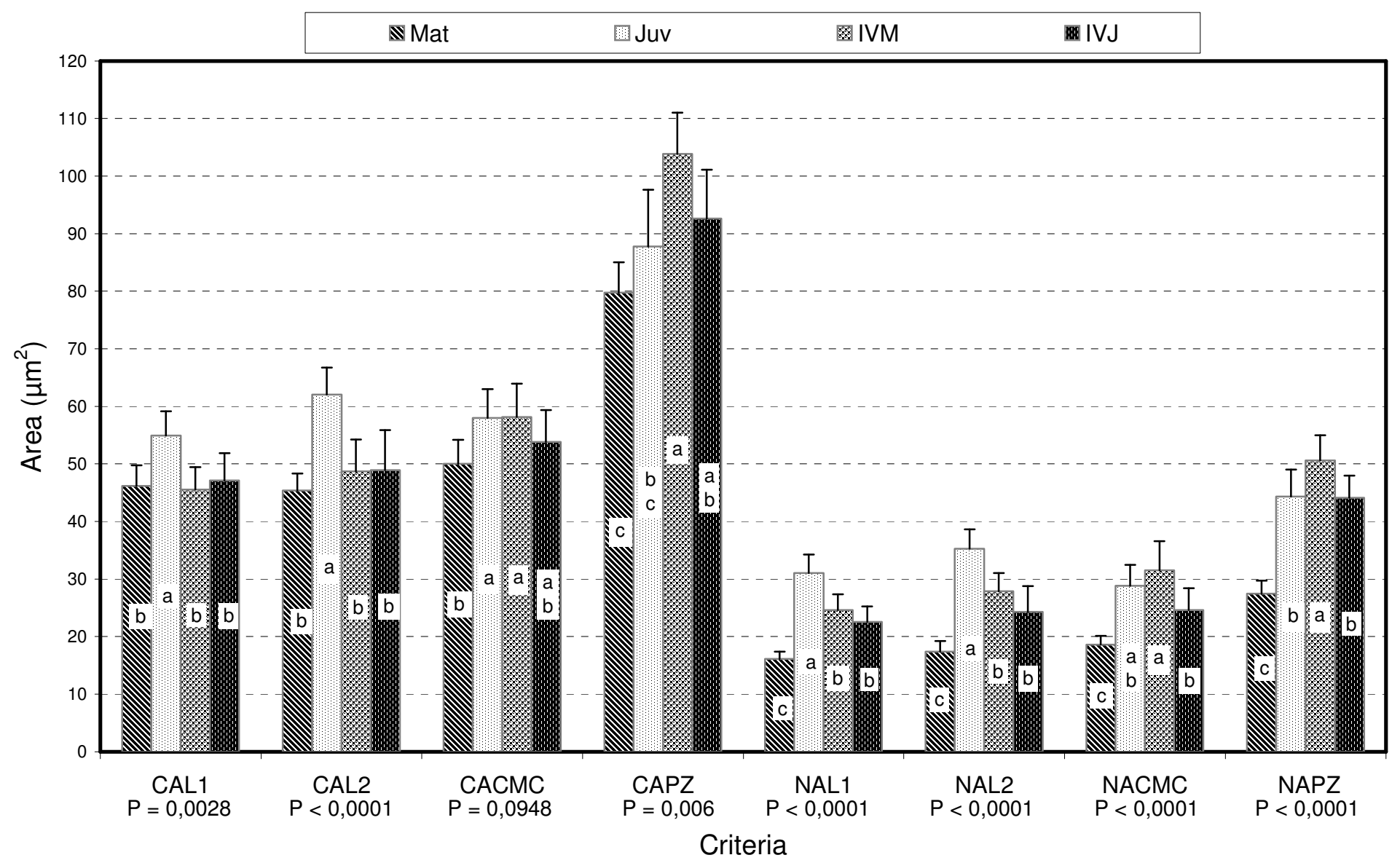

Fig. 10. Influence of the four SAM origins on measured cell (CA) and nuclear (NA) areas of $L 1, L 2, C M C$ and $P Z$ zones (with respective significance levels $P$ of the treatment). Bars represent confidence intervals at $\mathrm{Po}=5 \%$, and letters distinguish CA and NA mean values (established from 30 to 46 observations) which are significantly different for a given zone at the same $5 \%$ level. 


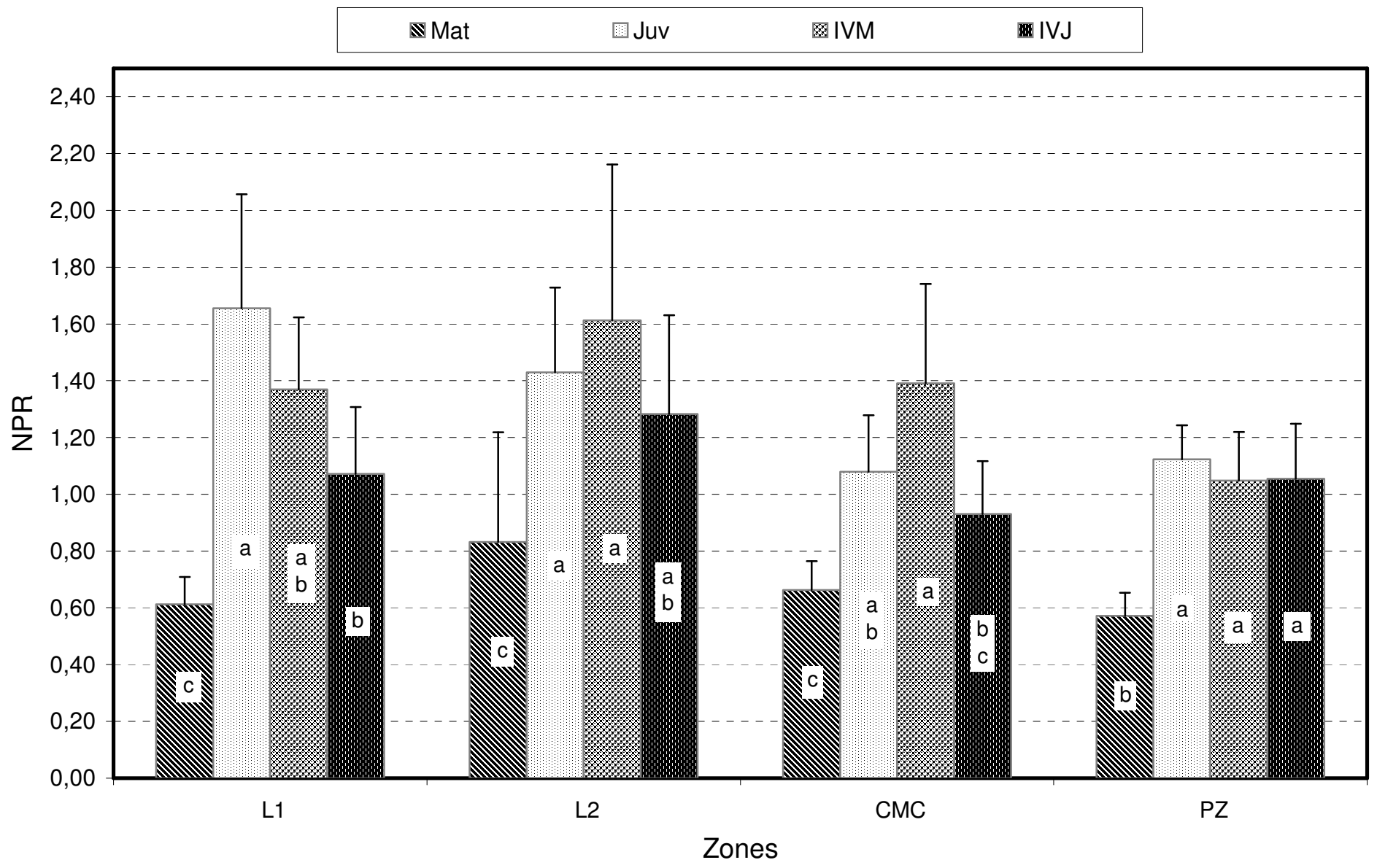

Fig. 11. Influence of the four SAM origins on nucleoplasmic ratios NPR of $L 1(P<0.0001)$, L2 $(P=0.0388), C M C(P=0.0003)$ and $P Z(P<0.0001)$ zones. Bars represent confidence intervals at $\mathrm{Po}=5 \%$, and letters distinguish mean values (established from 30 to 46 observations) which are significantly different for a given zone at the same $5 \%$ level. 

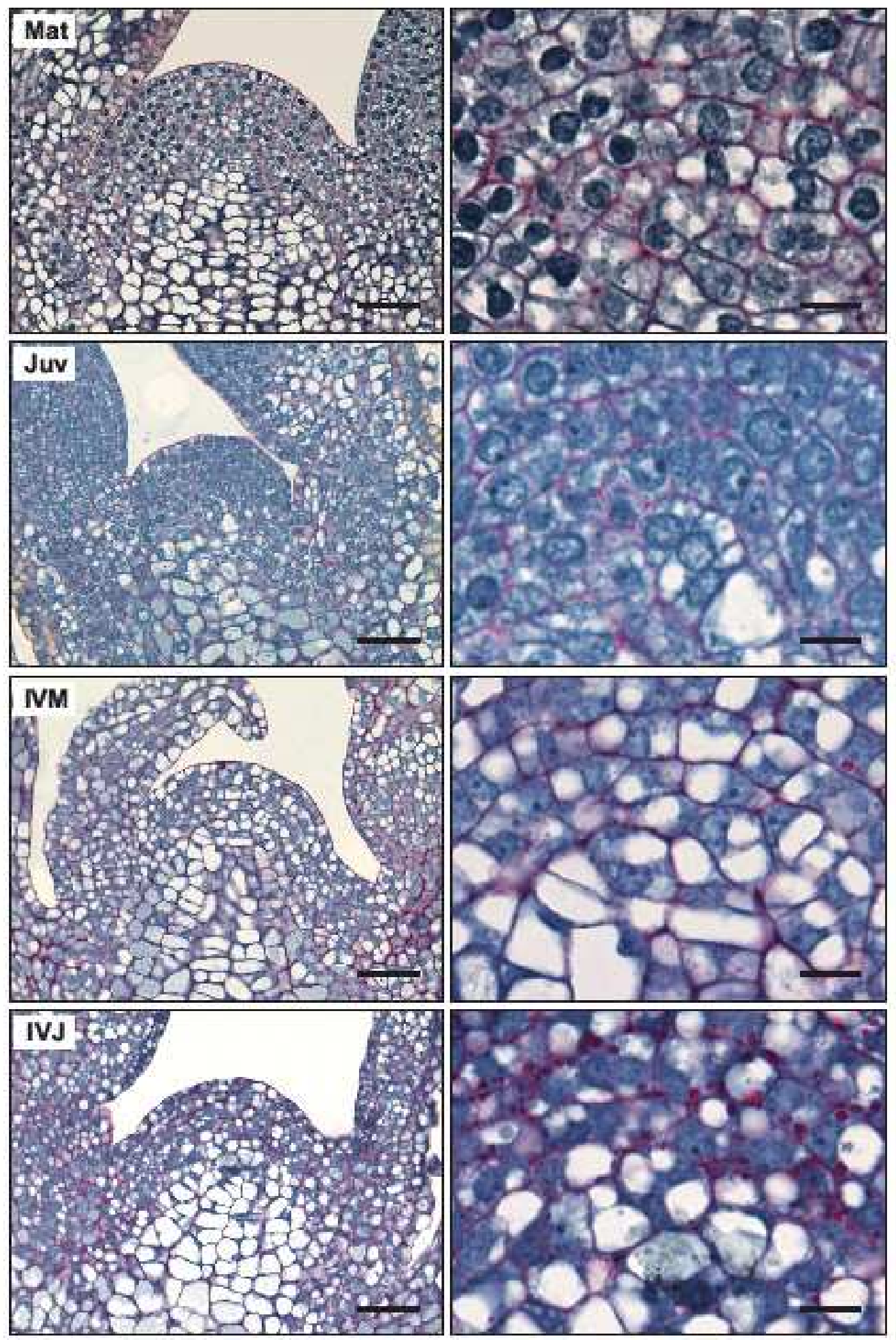

Fig. 12. Representative longitudinal median sections (scale bars are $20 \mu \mathrm{m}$ long) with magnification boxes (on the right, scale bars are $8 \mu \mathrm{m}$ long) of the four $A$. mangium SAM origins observed, i.e. from top to bottom: Mat: Mature, Juv: Juvenile, IVM: In vitro mature, IVJ: In vitro juvenile, showing abundant starch granules intensively stained in pink by PAS. 

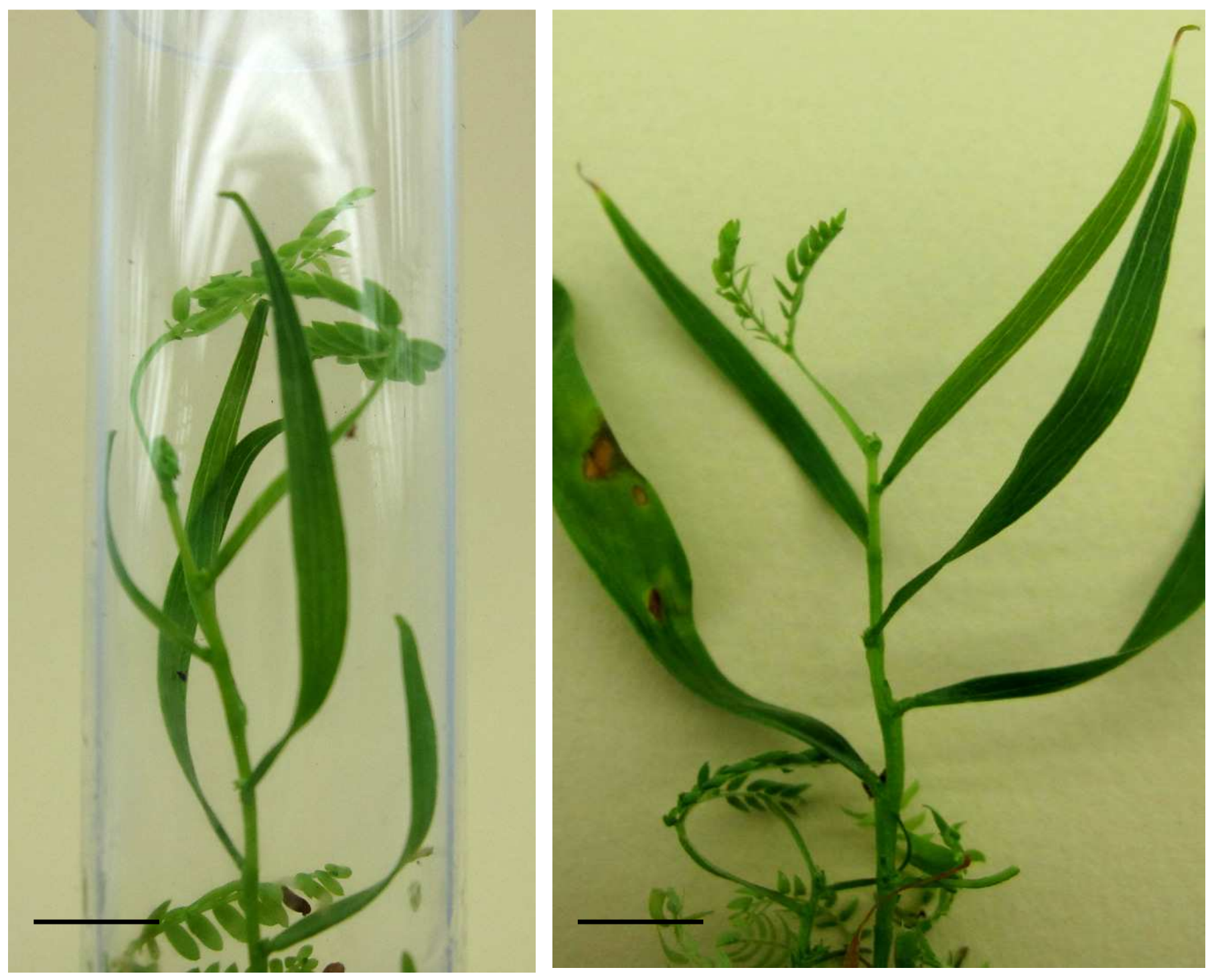

Fig. 13 : Morphological reversion from the mature phyllodes to the juvenile compound leaves at the shoot tip level of tissue-cultured microshoots from a mature selected $A$. mangium clone. Note that the axillary shoots from the bottom of the microshoots exhibit of the juvenile-like compound leaves (scale bars are $1 \mathrm{~cm}$ long). 